\title{
PRIMJENJIVOST NUŽNE OBRANE KOD KAZNENOG DJELA MUČENJA ILI UBIJANJA ŽIVOTINJE
}

Tomislav Nedić, mag. iur.*

\author{
UDK: $343.62: 59$ \\ Ur.: 12. listopada 2016. \\ Pr.: 19. prosinca 2016. \\ Izvorni znanstveni rad
}

\section{Sažetak}

Autor se u radu bavi problemom primjene instituta nužne obrane kod kaznenog djela mučenja ili ubijanja životinje. Polazeći od zakonske definicije nužne obrane, postavlja pitanje njezina tumačenja u dijelu koji se odnosi na nužnu pomoć (odbijanje napada „od drugoga“). Konkretno, pokušava se razraditi središnje, ali i najkontroverznije pitanje može li se istodobni protupravni napad odbijati i od životinje, odnosno jesu li život i tjelesna cjelovitost životinje pravna dobra koja se mogu štititi nužnom obranom. Ukratko se razrađuje $i$ problematika životinjskoga pravnog subjektiviteta i objektiviteta. Uvažavajući hrvatsku i američku sudsku praksu (u kojoj za razliku od hrvatske sudske prakse mučenje ili ubijanje životinje nije novina), autor pokušava hipotetski dočarati kakvi bi se predmeti mogli naći i pred našim pravosuđem te kako bi ih naši sudovi mogli i trebali rješavati. Također, komparativnopravno analiziraju se stavovi iz njemačke pravne literature u vezi s primjenom nužne obrane kod ovoga kaznenog djela. Krajnji je cilj stvoriti mehanizam koji neće obeshrabriti pomagače životinja da u granicama nužne obrane, odnosno nužne pomoći (bez njezina prekoračenja) spriječe njihovo mučenje ili ubijanje te da životinji, koja kao dio okoliša predstavlja Kaznenim zakonom zaštićeno pravno dobro, omogući ostvarivanje (načelima prirodnog prava zajamčenog) prava na život $i$ tjelesnu cjelovitost.

Ključne riječi: nužna obrana, nužna pomoć, krajnja nužda, životinja, Kazneni zakon.

* Tomislav Nedić, mag. iur., doktorand Pravnog fakulteta u Osijeku, Sveučilište J. J. Strossmayera u Osijeku; nedict@gmail.com 


\section{UVODNA RAZMATRANJA I NAPOMENE}

\subsection{Mučenje ili ubijanje životinje kao kazneno djelo protiv okoliša}

Kaznena djela protiv okoliša smještena su u glavi XX. Kaznenog zakona ${ }^{1}$ (dalje u tekstu: KZ). Njihovo reguliranje predstavlja novinu za hrvatsko kazneno zakonodavstvo, ali i druga poredbena zakonodavstva. U njima se očituje intencija zakonodavca da ide u korak s vremenom, sprječavajući sve one radnje koje su uglavnom vezane uz eksploataciju okoliša na njegovu štetu. Vrlo se često postavlja pitanje koliko su određeni pravni instituti primjenjivi kod ovih kaznenih djela te ako i jesu u kojoj su mjeri primjenjivi.

Sukladno znatnoj opasnosti od onečišćenja okoliša i njezinom sve učestalijem ostvarivanju, ali i zbog drugih protupravnih radnji povezanih uz sam okoliš, bilo je potrebno utemeljiti novu pravnu disciplinu prava okoliša.

Definicija okoliša središnja je, ali i kontroverzna problematika prava okoliša. ${ }^{2}$ Sama definicija odnosi se na gotovo svako „okruženje/okolicu“, no to je prilično relativan pojam i može se odnositi na gotovo svaki objekt u samom okruženju/ okolici. ${ }^{3}$ Jedna od definicija okoliša koja se daje u stranoj literaturi jest sveopće zajedničko, fizičko okruženje koje uključuje zrak, svemir, vodu, kopno, biljni i životinjski svijet, odnosno sve one neljudski stvorene medije. ${ }^{4}$

U nas je pravo na zdrav okoliš regulirano pomoću nekoliko različitih pravnih akata. Nastojeći usvojiti ustavni dokument koji će biti na tragu vremena ustavotvorac je konstitucionalizirao "očuvanje prirode i čovjekova okoliša" u članku 3. Ustava kao jednu od najviših ustavnih vrednota ustavnog poretka Republike Hrvatske, a u članku 69. Ustava "pravo na zdrav okoliš". 5

Građanskopravna zaštita okoliša u RH ima dvojaku ulogu. Prvenstvena uloga bila bi preventivne prirode (načelo preventivnosti), radi sprječavanja nastanka štete u okolišu, dok je druga, podredna uloga, represivne prirode (represivna zaštita) radi saniranja posljedica nastalih onečišćavanjem okoliša. ${ }^{6}$

Prema Zakonu o zaštiti okoliša ${ }^{7}$, okoliš se definira nešto drukčije nego u stranoj literaturi, kao prirodno i svako drugo okruženje organizama i njihovih zajednica uključivo i čovjeka, koji omogućuje njihovo postojanje i njihov daljnji razvoj: zrak, more, vode, tlo, zemljina kamena kora, energija te materijalna dobra $\mathrm{i}$ kulturna baština kao dio okruženja koje je stvorio čovjek; svi u svojoj raznolikosti i ukupnosti uzajamnog djelovanja.

1 Kazneni zakon, NN, br. 125/11., 144/12., 56/15., 61/15.

2 Bell, S. i dr., Environmental Law, Oxford University Press, 8. ed., 2013, str. 7.

3 Loc. cit.

4 Loc. cit.

5 Bačić, A., Ustavni temelji i problemi zaštite okoliša u hrvatskom i europskom pravu, Zbornik radova Pravnog fakulteta u Splitu, god. 45., 4/2008., str. 727.-743.

6 Proso, M., Građanskopravna odgovornost u području zaštite okoliša, Zbornik radova Pravnog fakulteta u Splitu, god. 52., 3/2015., str. 705.- 719.

7 Zakon o zaštiti okoliša, NN, br. 80/13., 153/13., 78/15. 
Razmatranjem ove definicije jasno je zašto je kazneno djelo mučenja ili zaštite životinja smješteno upravo u ovu glavu KZ-a.

Prema Ascioneu mučenje životinja definira se kao „društveno neprihvatljivo ponašanje koje uključuje namjeru nanošenja nepotrebne boli, patnje, neugode i/ili smrti životinji.“8 Kazneno djelo ubijanja ili mučenja životinja regulirano je člankom 205. KZ-a gdje je za temeljni oblik kaznenog djela predviđeno da će se kaznom zatvora do jedne godine kazniti ona osoba koja usmrti životinju bez opravdanog razloga ili je teško zlostavlja, nanosi joj nepotrebne boli ili je izlaže nepotrebnim patnjama. Time je novi KZ ukinuo mogućnost da se za ubijanje ili mučenje životinja propisuje novčana kazna, kao što je to bilo u starom KZ-u. Kod temeljnog oblika kažnjava se za namjerno nanošenje boli, patnje, ozljeda i izlaganje strahu životinja, točnije mora se raditi o izravnoj namjeri. U literaturi još uvijek postoje dvojbe može li djelo biti počinjeno i s neizravnom namjerom. Prema Turković et al., djelo mora biti počinjeno s izravnom namjerom, a ako takva namjera ne postoji, može se raditi o prekršaju iz članka 66. stavka 1. točke 1 . Zakona o zaštiti životinja. ${ }^{9}$ Prema Pavloviću, neprihvatljivo je stajalište da djelo mora biti počinjeno $\mathrm{s}$ izravnom namjerom jer nije teško zamisliti situaciju u kojoj je netko svjestan da svojom radnjom može bez opravdanog razloga usmrtiti životinju ili joj nanijeti nepotrebne boli ili je izložiti nepotrebnim patnjama ili je zlostavljati pa unatoč tome na to pristaje. ${ }^{10}$ Sukladno navedenom, potrebno je naglasiti kako će se u praksi kod ovog kaznenog djela uglavnom pojavljivati izravna namjera, ali time nije isključena ni mogućnost počiniteljeva postupanja s neizravnom namjerom.

Kvalificirani oblik predviđen je stavkom 2. gdje će se kazniti do dvije godine zatvora ona osoba koja kazneno djelo počini iz koristoljublja čime je kazna povećana s kazne zatvora do jedne godine na kaznu zatvora do dvije godine. Stavak treći predviđa i nehajnu odgovornost gdje će se osoba koja nehajem uskratom hrane ili vode ili na drugi način izloži životinju tegobnom stanju kroz dulje vrijeme, kazniti kaznom zatvora do šest mjeseci.

Novost je odredba iz stavka 4. da se zlostavljana životinja, koja preživi zlostavljanje, oduzima zlostavljaču čime je učinjen veliki pozitivan korak u zaštiti životinja jer se dosad, zbog nepostojanja zakonske regulative, zlostavljana životinja, nakon oporavka od ozljeda i pružene veterinarske pomoći, vraćala zlostavljaču. ${ }^{11}$

Djelo je, s obzirom na počinitelja, koncipirano kao delictum communium, može ga počiniti svatko, neovisno o vlasništvu ili posjedu nad životinjom, a također dolazi u obzir i odgovornost pravnih osoba za ovo kazneno djelo, napose glede nehajnog oblika. ${ }^{12}$

8 Ascione, F. R., Children who are cruel to animals: A review of research and implications for developmental psychopathology. Anthrozoös, 6, 1993., str. 226-247.

9 Turkovć, K. i dr., Komentar Kaznenog zakona, Narodne novine, Zagreb, 2013., str. 278.

10 Pavlović, Š., Kazneni zakon. Zakonski tekst, komentari, sudska praksa, pravna teorija, Libertin, Rijeka, 2015., str. 919.

11 Službene stranice Ius-info, viđeno: 7.6.2016., URL: http://www.iusinfo.hr/DailyContent/News.aspx?id=14566

12 Novoselec, P. (ur.), Posebni dio kaznenog prava, Pravni fakultet Sveučilišta u Zagrebu, Zagreb, 2011., str. 285. 
Zbog blanketne prirode odredbi KZ-a, ovdje dolazi u obzir primjena Zakona o zaštiti okoliša, Zakona o zaštiti životinja ${ }^{13}$ te Zakona o zaštiti prirode ${ }^{14}$.

\subsection{Razlozi pisanja i ciljevi rada}

Kao i kod drugih kaznenih djela protiv okoliša, tako se i kod kaznenog djela mučenja ili ubijanja životinje postavlja zanimljivo pitanje je li i u kojoj mjeri institut nužne obrane primjenjiv kod ovog kaznenog djela. Također, naša je sudska praksa oko kaznenog djela ubijanja ili mučenja životinje prilično oskudna, što i nije čudno jer ovo kazneno djelo nije dugo ustaljeno u hrvatskom kaznenom zakonodavstvu, iako broj počinitelja svakodnevno sve više raste. Situacija je drukčija u SAD-u gdje su se sudovi često našli u situaciji da institut krajnje nužde primjenjuju upravo kod ovog kaznenog djela te će se, komparativnopravno, u radu obrađivati i njihova sudska praksa. Budući da je granica između nužne obrane i krajnje nužde katkada dosta mala, američka sudska praksa u kojoj se kod ovog kaznenog djela primjenjuje krajnja nužda može uvelike biti korisna našim sudovima kako se ne bi našli u nedoumici koji od ta dva kaznenopravna instituta primijeniti. Uz to, autor komparativnopravno razrađuje i analizira stavove iz njemačke pravne literature koja tradicionalno utječe na hrvatsko kazneno pravo.

Postavljeno pitanje zahtijeva teorijsku i praktičnu razradu. Teorijski aspekt ogleda se u tome da se primjenjivost nužne obrane kod kaznenog djela mučenja ili ubijanja životinje pokuša razraditi primjenom postignuća moderne kaznenopravne dogmatike, a praktični aspekt $u$ analizi stvarnih ili hipotetičkih postupanja sudova $\mathrm{u}$ vezi s navedenim problemom, jer nije teško zamisliti situaciju u kojoj bi druga osoba priskočila u pomoć napadnutoj životinji i time napadaču, u granicama nužne pomoći, nanijela određene lake ili čak teške tjelesne ozljede, radi zaštite napadnute životinje.

Sukladno navedenom, ciljevi su ovog rada:

- Teorijska razrada instituta nužne obrane kod kaznenog djela mučenja ili ubijanja životinje te odgovaranje na pitanje je li moguće i na koji način, u teorijskom smislu, iz kuta kaznenopravne dogmatike te komparativnopravno, ovaj institut primijeniti kod ovog kaznenog djela. Pokušat će se odgovoriti i na pitanje može li se termin „od drugoga“ odnositi i na životinju.

- Praktična razrada gdje će se hipotetski, korištenjem domaće i strane sudske prakse, pokušati simulirati moguće realne situacije koje bi zahtijevale primjenu krajnje nužde ili nužne obrane kao isključenja protupravnosti kaznenog djela.

13 Zakon o zaštiti životinja, NN, br. 135/06., 37/13., 125/13.

14 Zakon o zaštiti prirode, NN, br. 80/13. 


\section{NUŽNA OBRANA KOD KAZNENOG DJELA MUČENJA ILI UBIJANJA ŽIVOTINJE}

\subsection{Razlozi priznanja instituta nužne obrane kod ovog kaznenog djela}

Potrebno je razlikovati situaciju u kojoj je ispunjenje bića kaznenog djela iz članka 205. KZ-a opravdano nužnom obranom (npr. ubijanje životinje koju napadač koristi kao sredstvo napada) i situaciju u kojoj se optuženik poziva na nužnu obranu jer je odbijao (sprječavao) protupravni napad na životinju (,od drugoga“) koji se očitovao u pokušaju ostvarivanja bića navedenog kaznenog djela. U radu će biti razmatrana potonja situacija, odnosno pitanje može li se u slučaju napada na životinju u kontekstu kaznenog djela mučenja ili ubijanja životinje takav napad odbijati ,od drugoga“.

Nužna obrana bazira se na dva temeljna načela: načelu samozaštite i načelu afirmacije prava u odnosu na nepravo.

Prema načelu samozaštite nitko nije dužan trpjeti povrede svojih pravnih dobara i ovlašten je na njih uzvratiti silom. U tom slučaju država odustaje od monopola na uporabu sile jer ne može uvijek biti prisutna kada je to potrebno. ${ }^{15}$

Međutim, jedan od glavnih razloga priznanja ovog instituta kod kaznenog djela mučenja ili ubijanja životinje leži u načelu afirmacije prava u odnosu na nepravo. Prema tom načelu osigurava se prevlast prava u odnosu na nepravo jer napadač ne ugrožava samo tuđe individualno pravo nego i niječe pravni poredak i utoliko predstavlja nepravo, dok napadnuti ne brani samo svoje ili tuđe individualno dobro nego i pravni poredak u cjelini i utoliko predstavlja pravo. ${ }^{16}$

Stoga je ispravno istaknuo VSH (I Kž- 799/76, Pregled 10, 52) da se nužnom obranom može odbijati protupravni napad na svako dobro zaštićeno kaznenim pravom, a samo kao primjere naveo je život, slobodu, imovinu i čast. ${ }^{17}$ Mučenje ili ubijanje životinje kao kazneno djelo inkriminirano je KZ-om te Zakonom o zaštiti životinja kao nužnom referencom na blanketne odredbe KZ-a. Time se štiti život i tjelesna cjelovitost životinje koja je dio okoliša.

Ako slučajni prolaznik uoči da dvije osobe zlostavljaju mačku stavljajući joj pirotehničke naprave u usta koje namjeravaju zapaliti, moguće da će htjeti reagirati da ih zaustavi u tome i da će morati upotrijebiti i određenu silu da spriječi napadače. Ovim činom slučajnog prolaznika uistinu se zaštićuje pravo u odnosu na nepravo što je jedan od temeljnih načela instituta nužne obrane. Ako bi u ovom slučaju isključili primjenu nužne obrane, tada bi eventualni počinitelj mogao odgovarati za nanošenje lakih tjelesnih ozljeda što nije sasvim ispravna kvalifikacija jer je imao za namjeru pomoći životinji koja je inferiorna napadačima i jer je istim činom za namjeru imao spriječiti počinjenje kaznenog djela.

15 Novoselec, P., Bojanić, I., Opći dio kaznenog prava, Pravni fakultet Sveučilišta u Zagrebu, Zagreb, 2013. str. 168.

16 Loc. cit.

17 Ibid., str. 169. 
Nekoliko puta se prigovaralo da hrvatski sustav zaštite životinja nije dovoljno učinkovit. ${ }^{18} \mathrm{U}$ tom pogledu je potrebno reagirati neposredno jer sama inkriminacija kaznenog djela ne znači da isto neće biti počinjeno, čak štoviše isto se kazneno djelo čini često i nekoliko je puta zabilježeno u praksi hrvatskoga sudstva. U hipotetski već navedenoj situaciji, ako dva napadača na ulici zlostavljaju mačku stavljajući joj pirotehničke naprave u usta koje namjeravaju zapaliti, utoliko je potrebna hitna reakcija da se spriječi sama posljedica, a to je dobrim dijelom moguće koristeći nužnu obranu. Nadalje, ovakva reakcija predstavlja možda i jedini instrument slučajnog prolaznika, jer on nije obvezan zaustavljati napadače u njihovom činu i ne može odgovarati za nečinjenje jer nije garant zlostavljanoj životinji.

Nema previše spornih situacija ako je napadnuta životinja u vlasništvu druge osobe. Tada ta osoba zasigurno ima pravo na nužnu obranu jer se nužnom obranom smije štititi i vlastita imovina, uz to da se druga osoba ne smije usmrtiti. No, postavlja se pitanje što ako slučajni prolaznik štiti životinju koja nije u ničijem vlasništvu. Tada se institut nužne obrane treba proširiti i na druga dobra, a koja proistječu i iz već spomenute odluke našeg VSRH-a koji ima takvu intenciju. Intencija postaje tim bitnija ako se potkrijepi i argumentira već navedenom činjenicom da bi se, u zakonom priznatim granicama, trebala priznati svaka zaštita onog pravog dobra koje je zaštićeno KZ-om. Život i tjelesna cjelovitost životinje jesu jedna od njih, a ono emanira upravo iz reguliranoga kaznenog djela mučenja ili ubijanja životinje. Potrebno je naglasiti da navedeno stajalište VSRH-a ponajprije proizlazi iz činjenice da zakonska odredba o nužnoj obrani ne postavlja nikakva ograničenja u pogledu pravnih dobara koja se mogu štititi nužnom obranom (za razliku od nekih drugih zakonodavstava, primjerice, austrijskoga KZ-a).

\section{2. Životinja kao objekt ili čak i subjekt prava}

Pojam životinjskih prava svakog se dana sve više razvija i oblikuje. Ako životinje imaju svoja prava, jesu li one onda i pravni subjekti? Ovdje dolazimo do prilično spornog pitanja koje je potrebno razjasniti za potrebe samog rada.

Do sada su se životinje bez bilo kakvih nedoumica tretirale kao pravni objekti, odnosno kao stvari. Međutim, postoji tendencija koja ide za tim da se životinji da i pravni subjektivitet. Kada bi se životinjama i dao pravni subjektivitet to ne znači da one više ne bi bile subjekti skrbništva i kontrole od ljudskih bića, nego samo to da ljudi više ne bi bili vlasnici životinja. ${ }^{19}$ Odnos između čovjeka i životinje bio bi sličniji odnosu između roditelja i djeteta ili duševno bolesne osobe i njezina zakonskog zastupnika. ${ }^{20}$ Međutim, ako životinje ne mogu razlikovati između dobrog i lošeg postupanja, tada ne pripadaju istoj moralnoj zajednici kao ljudska bića pa

18 Vidi više na Službenim stranicama Ius-info, viđeno: 7.6.2016.

URL: http://www.iusinfo.hr/DailyContent/News.aspx?id=15803

19 Adams, W. A., Human subjects and animal objects: Animals as "other" in the law, Journal of Animal Law and Ethics, vol. 3., 2009., str. 29.-51.

20 Usp. ibid. 
samim time i ne mogu imati pravni subjektivitet koji uključuje određena prava, ali i obveze. $^{21}$

Unatoč raspravama, činjenica je da se životinjama, koja su živa bića poput ljudi, trebaju priznati temeljna prava, a koja se odnose na njihovu životnu opstojnost i cjelovitost, a koja emaniraju iz postavki prirodnog prava. ${ }^{22}$ Isto je prepoznao $\mathrm{i}$ hrvatski zakonodavac koji je u KZ-u regulirao kazneno djelo mučenja ili ubijanja životinje gdje se životinji priznaje pravo na život i tjelesnu cjelovitost. Ta ista prava nisu samo proistekla iz životinje kao nositelja prava, nego više iz suživota i odnosa s čovjekom gdje se od čovjeka traži moralnost i nenasilno ponašanje u odnosu na samu životinju koja je živo biće isto kao i čovjek. Jer, kako se pitao Visković, „kako spriječiti nepravedno upadanje prava jednih bića u prava drugih bića, tj. razornu apsolutizaciju ičijih prava?" 23 Tretirati životinju s poštovanjem nije puki izraz ljubaznosti, nego same pravde, tretiranja životinja prema njihovim svojstvenim vrijednostima. ${ }^{24}$ Čovjek koji je moćan djelovati doveo je životinje u ovisnost o sebi i zbog toga je obvezan voditi računa o njihovim interesima i pravima koja iz njih proizlaze. ${ }^{25}$ Autonomija čovjeka ima uzajamni odnos s odgovornošću za njegovo postupanje te bez ove odgovornosti nema ni ljudskog dostojanstva jer što je veći odnos ovisnosti životinja od moćno-djelujućeg i za individualno samoodređivanje sposobnog čovjeka, utoliko aktualnija postaje njegova odgovornost. ${ }^{26}$

Prema Jakovljeviću temeljna životinjska prava jesu: ${ }^{27}$

1. Pravo na život i opstanak u mjeri svojstvenih organskih funkcionalnih mogućnosti održivosti svake životinjske vrste i jedinke, na tjelesnu nepovredivost i sigurnost, tj. neugroženost.

2. Pravo na svoju nenarušenu prirodnu životnu sredinu, biosferu - kao pretpostavku za (1.) te za mogućnost nesmetanog zadovoljavanja osnovnih organskih potreba unutar te sredine.

3. Pravo na neometani i nemanipulirani, autonomno-spontani individualni i vrsni razvoj te potencijalne mutacije, uključujući, dakle, pravo na zaštitu od zahvata u njihovu genetsku supstancu kojima bi se konvencionalno, prema svojevoljnom nahođenju ljudi, mijenjao njihov genetski kod. (Posljednje posebno s obzirom na okolnost da je prema aktualnom stanju medicinske znanosti manipulacija genoma živih bića ireverzibilna.)

21 Ibid.

22 Vidi više u Epstein, R. A., Animals as Objects, or Subjects, of Rights, John M. Olin Law \& Economics working paper no. 171 (2D series), The Law School, The University of Chicago, December 2, 2002.

23 Visković, N., Kulturna zoologija, Što je životinja čovjeku i što je čovjek životinji, Naklada Jesenski i Turk, Zagreb, 2009., str. 394.-395.

24 Armstrong, S. J., Botzler, R., G., The Animal Ethics Reader, Routledge, 2003., str. 21.

25 Kaluđerović, Ž., Bioetički pristup životinjama, Socijalna ekologija, Zagreb, vol. 18., br. 3-4, 2009., str. 311-322.

26 Ibid.

27 Jakovljević, D., Prava za životinje, Filozofska istraživanja, 129, god. 33., sv. 1., 2013., str. 167.-182. 
4. Pravo na zaštitu od svih takvih zahvata u njihove živote i postupke prema njima kojima im se nanose šteta, bol i patnja. Ujedno pravo na pružanje pomoći u slučajevima narušenog zdravstvenog stanja, bolesti koje ugrožavaju njihovu tjelesno-mentalnu dobrobit, a u granicama svagdašnje praktikabilnosti takve pomoći.

5. Kod divljih životinja pravo na samosvojno življenje, bez prinudnog podčinjavanja interesima i potrebama ljudi - a, ponajprije, takvih podčinjavanja koja su u velikoj disharmoniji s onim što se može smatrati vlastitim prirođenim načinom življenja te temeljnim prirodnim potrebama samih životinja i onih koja bi uključivala povredu prava (4.) te eventualno služila određenim destruktivnim svrhama.

6. Kod domaćih životinja pravo na pružanje određenog neophodnog minimuma kvalitete življenja, tj. životnih uvjeta, uključujući ne samo smještajne uvjete, redovno prehranjivanje, nego i socijalne kontakte s pripadnicima iste vrste, ako one za time imaju potrebu. Također, pravo na zaštićenost od prekomjernog izrabljivanja u ljudske poslovne svrhe i s time povezanih psiho-fizičkih prenaprezanja. Šire uzevši: pravo na nezanemarivanje, odnosno posvećivanje minimuma pažnje domaćim životinjama i njihovim potrebama, osobito u uvjetima njihova masovnijeg uzgoja te na nesluženje destruktivnim ljudskim ciljevima.

Nadalje, Jakovljević pritom smatra ${ }^{28}$ da bi iznimka od temeljnog prava (1.), i u tom slijedu i ostalih s njime povezanih i izvedenih prava kojih je ono preduvjet, bio dopustiv jedino u sljedeća četiri slučaja:

a) Kada održavanje određenih životinjskih jedinki odnosno grupa u životu predstavlja veliku opasnost za ostale vrste živih bića - npr. zbog širenja teških ili neizlječivih zaraznih bolesti, i nema drugih primjenjivih načina suzbijanja te opasnosti osim uspavljivanja zaraženih jedinki.

b) U slučajevima samoobrane, tj. kada je ljude napala neka životinja, pri čemu njeno neutraliziranje putem ranjavanja ili usmrćivanja predstavlja jedino praktikabilni situacijski imperativ zaštite samih ugroženih ljudi i njihove imovine.

Ovdje se, ovisno o danoj situaciji i određenim okolnostima, primjenjuju pravila o nužnoj obrani ili krajnjoj nuždi.

c) Ako vrijedi: neke životinje su nezamjenjiva hrana za ljude kao mesojede te ako usmrćivanje jednih predstavlja uvjet preživljavanja i opstanka, održavanja u životu drugih.

d) Unutar situacija kada su određene životinje beznadno oboljele ili teško, nepopravljivo povrijeđene, paralizirane itd., te kada, dakle, njihovo daljnje održavanje na životu predstavlja samo produljenje mučne agonije i dalje umnožavanje njihovih intenzivnih patnji. Radi se o slučajevima upućenosti na eutanaziju, prije čijeg poduzimanja bi se, međutim, brižljivo moralo procijeniti ukupno stanje svake životinjske jedinke kako bi odluka bila donesena na temelju što pouzdanijih uvida. A to znači i u uvjetima najbolje raspoložive izvjesnosti u pogledu toga 
da, poduzimajući takav nepovratan korak, nismo počinili pogrešku, nego da je uspavljivanje predstavljalo upravo moralno dopustivo i primjereno rješenje $s$ obzirom na danosti objektivnoga stanja određenih životinjskih jedinki.

Iako se pojam životinjskih prava svakim danom sve više razvija, teško je zamisliti da bi hrvatski sudovi priznali pravni subjektivitet životinjama. To se općenito ne odnosi samo na hrvatske sudove, nego i na druge inozemne sudove, budući da životinja još uvijek nije subjekt prava u klasičnom smislu te riječi te je prema određenim istraživanjima sve više situacija gdje sudovi razmatraju problematiku subjektiviteta životinja. ${ }^{29}$ Životinja jest objekt prava, ali ne klasični objekt prava poput neke materijalne stvari. Ono je živo biće koje ipak ima određena prava, a koja se odnose na njezin život i tjelesnu cjelovitost, a što proizlazi iz temeljnih načela prirodnog prava. Svaka životinja ima pravo na život i na uvažavanje svega onoga što ljudi uvažavaju jedni kod drugih. ${ }^{30}$ Kao što je neprihvatljivo da jedan čovjek ili jedna ljudska skupina ugnjetavaju druge pojedince ili skupine temeljem rasne, spolne, dobne ili bilo koje druge razlike, tako je neprihvatljivo da ljudska vrsta ugnjetava sve druge vrste. ${ }^{31}$

Međutim, kako je to napravio i sam zakonodavac reguliravši mučenje ili ubijanje životinje kao kazneno djelo, tada i sudovi moraju priznati temeljno pravo životinje zaštićeno KZ-om, a odnosi se život i tjelesnu cjelovitost životinje. Ovo predstavlja jak argument kod priznanja nužne obrane kod ovog kaznenog djela jer je potrebno na bilo koji način zaštititi ono dobro koje zaštićuje i sam KZ.

U ovom slučaju neće se razmatrati činjenica da se od sebe odbije protupravni napad, nego „od drugoga“, jer životinja još uvijek nije subjekt prava i samim time joj se ne može priznati pravo na nužnu obranu. Životinja je objekt prava i u tom ćemo smislu razmatrati daljnju razradu oko (ne)priznanja nužne obrane kod ovog kaznenog djela. Stoga u radu razlikujemo dvije situacije:

a) životinja je u vlasništvu određene osobe i

b) životinja nije u vlasništvu nijedne osobe.

\section{3. Životinja u vlasništvu određene osobe}

U praksi hrvatskih sudova najčešće se priznaje nužna obrana kada se štiti život, tjelesna cjelovitost i sloboda, dok se načelno priznaje i pravo na nužnu obranu u slučaju zaštite imovine i časti. ${ }^{32}$ Ako je napadnuta životinja u vlasništvu određene osobe, ista osoba, odnosno vlasnik ima ju pravo zaštititi na temelju činjenice da štiti svoju imovinu.

29 Vidi više u Ascione, F. R., Lockwood, R., Cruelty to animals: Changing psychological, social, and legislative perspectives. In D.J. Salem \& A.N. Rowan (Eds.), The state of the animals, 2001., str. 39.-53., Washington, DC: Humane Society Press

30 Kovačević, B., Manifest pokreta za prava životinja: o speciesizmu ili diskriminaciji na osnovi vrste, Revija za sociologiju, vol. 40., br. 3., 2010., str. 337.-343.

31 Ibid.

32 Novoselec, P., Bojanić, I. op. cit. (bilj. 15.), str. 169. 
Pokušajmo istu situaciju hipotetski dočarati primjerom iz naše sudske prakse u predmetu optuženika koji je psa isjekao kliještima po vratu i ostavio ga da ugine. ${ }^{33}$

Optuženik, star 38 godina, po zanimanju tesar sa završenom srednjom građevinskom školom, uzeo je 14. ožujka 1998. psa obitelji s kojom je bio u svađi, a zatim ga u obližnjem svinjcu kliještima za žicu isjekao po vratu i ostavio da krvari. Pas je cvilio i zavijao i nakon dva dana uginuo. Prvostupanjski je sud ocijenio da je optuženik na opisani način životinju izložio nepotrebnim mukama i nanio joj nepotrebne boli te da je počinio kazneno djelo mučenja životinje iz članka 260. stavka 1. KZ-a. Za to djelo izrekao mu je kaznu zatvora u trajanju od pet mjeseci koju je objedinio s kaznom zatvora u trajanju od deset mjeseci za jedno drugo prije počinjeno kazneno djelo i osudio ga na uvjetnu osudu. Drugostupanjski je sud našao da nema uvjeta za uvjetnu osudu pa ga je osudio na jedinstvenu kaznu zatvora u trajanju od jedanaest mjeseci. Poslije je VSRH kaznu izvanredno ublažio i ponovo izrekao uvjetnu osudu. ${ }^{34}$

U ovoj je situaciji vlasnik ubijenog psa imao pravo na nužnu obranu svoje imovine kako bi od napadača odbio protupravni napad na svojeg psa, odnosno na svoju imovinu. U prilog navedenom ide i činjenica da je počinitelj u idealnom stjecaju počinio kazneno djelo mučenja životinje i kazneno djelo uništenja ili oštećenja tuđe stvari iz članka 222. stavka 1. KZ-a., budući da se zabranom mučenja životinje ne štiti i tuđe vlasništvo nad životinjom. ${ }^{35}$ Ipak u ovom postupku osuda i za to kazneno djelo nije bila moguća jer se kazneni postupak za uništenje i oštećenje tuđe stvari pokreće u povodu prijedloga, a njega nije bilo. ${ }^{36}$

No i ovdje je potrebno učiniti i određena ograničenja. Naime, ubojstvo radi zaštite imovine, za razliku od drugih zaštićenih pravnih dobara, nije dopušteno. To proizlazi iz Europske konvencije o zaštiti ljudskih prava i temeljnih sloboda ${ }^{37}$, točnije članka 2. stavka 2.a koji propisuje kako „lišenje života nije u suprotnosti s ovim člankom ako proizlazi iz upotrebe sile koja je apsolutno neophodna u obrani svakog pojedinca od nezakonitog nasilja." Kako je Republika Hrvatska članica Vijeća Europe te je samim time i ratificirala Konvenciju potrebno je u potpunosti isključiti namjerno ubojstvo kao oblik nužne obrane kod napada na imovinu te iznimno tražiti razmjernost napadnutog dobra i dobra koje se povređuje radnjom u

33 Županijski sud u Osijeku, Kž-329/02 od 28. 6. 2002. (Općinski sud u Belom Manastiru, K-61/02)

34 Predmet je u našoj kaznenopravnoj teoriji i praksi također zanimljiv po pitanju zablude u protupravnosti, posebno pođe li se od toga da je djelo počinjeno nedugo nakon stupanja na snagu Kaznenog zakona koji je prvi put predvidio mučenje životinje kao kazneno djelo. Sudovi istu činjenicu nisu uzimali u obzir pri izricanju kazne. Više o istom pitanju u Novoselec, P., Sudska praksa, Hrvatski ljetopis za kazneno pravo i praksu, vol. 11., br. 1/2004., str. 279.-284.

35 Novoselec, P., Sudska praksa, Hrvatski ljetopis za kazneno pravo i praksu, vol. 11., br. 1/2004, str. 279.-284.

36 Ibid.

37 Konvencija o zaštiti ljudskih prava i temeljnih sloboda, NN, MU, 18/97., 6/99., 14/02., 13/03., 9/05., 1/06., 2/10. 
nužnoj obrani, što inače zakon ne zahtijeva od nužne obrane, za razliku od krajnje nužde. ${ }^{38}$

Upravo krajnjom nuždom u predmetu State v. Hurd ${ }^{39}$ pravdao se pred sudom čovjek koji je ustrijelio susjedovog psa kako bi zaštitio vlastitu puricu koju je pas navodno proganjao. Isti je čovjek osuđen za okrutno postupanje prema životinji jer nije uspio dokazati da je pas bio u neposrednoj blizini purice. Ovdje je potrebno istaknuti činjenicu koja je primjenjiva i kod nužne obrane, a to je da namjera spašavanja sama za sebe nije dovoljna, već uz nju mora postojati onaj dokaz koji upućuje na to da je određeni akt spašavanja bio nužna potreba u tom trenutku, što optuženi u predmetu nije uspio dokazati jer pas nije bio u neposrednoj blizini purice, a time i nije postojala neposredna opasnost koja bi eventualno opravdala njegov čin. S obzirom na izloženo činjenično stanje dostatno je istaknuti da nije bilo neposredne (istodobne) opasnosti, tako da i nije bilo potrebno utvrđivati je li akt spašavanja bio nužno (prijeko) potreban.

Sukladno svemu navedenom, zaključno valja napomenuti da u situaciji kad je životinja u vlasništvu druge osobe primjena instituta nužne obrane uopće nije i ne bi trebala biti sporna.

\section{4. Životinja nije u vlasništvu nijedne osobe - primjena nužne pomoći}

Kod primjene nužne obrane radi zaštite životinje koja je u vlasništvu druge osobe situacija je jasna jer je imovinu kao pravno dobro dopušteno štititi nužnom obranom. Međutim, dvojbe i kontroverze javljaju se u situaciji kad životinja nije ni u čijem vlasništvu.

Kako je već zaključeno da je životinja još uvijek samo objekt prava, u ovom bi se slučaju trebalo govoriti o nužnoj pomoći kao inačici nužne obrane. Ponajprije je potrebno razmotriti osnovne postavke nužne pomoći. Nužna pomoć je nužna obrana kojom počinitelj odbija protupravni napad od drugoga, gdje je u prvom planu načelo potvrđivanja pravnog poretka. ${ }^{40}$ Upravo zbog nužne pomoći KZ ne zove nužnu obranu „samoobranom“ jer nužna obrana obuhvaća i odbijanje protupravnog napada od drugog. Također, kod nužne pomoći ne traži se nikakav poseban odnos između napadnutog i onoga tko pružna pomoć te sukladno tom svatko ima pravo pružiti pomoć napadnutom. ${ }^{41}$

Upravo ovdje možemo primijeniti već spomenutu hipotetsku situaciju slučajnog prolaznika. Smije li slučajni prolaznik koji primijeti kako dva napadača na bilo koji način zlostavljaju životinju na ulici stati u obranu životinje? Pitanje je praktično važno jer ako prolaznik pomažući životinji napadačima nanese lake ili čak teške tjelesne ozljede, odgovarat će za njih ako mu se ne prizna nužna pomoć kao razlog isključenja protupravnosti. Činjenica je da pojedinac ne bi trebao

38 Vidi više u Novoselec, P., Bojanić, I. op. cit. (bilj. 15.), str. 169.

39 Hurd v. State, 190 Md. App. 479 (Md. Ct. App. 2010)

40 Usp. Novoselec, P., Bojanić, I. op. cit. (bilj. 15.), str. 180.

41 Loc. cit. 
monopolizirati prava na fizičku prisilu u svakoj situaciji, ali je bitno istaknuti da je u navedenom slučaju nužna pomoć jedini instrument koji bi doveo do sprječavanja mučenja ili ubijanja životinje. Cilj odredbe o mučenju ili ubijanju životinje jest upravo zaštita života i tjelesnog integriteta životinje te ako slučajni prolaznik postupa u granicama nužne pomoći i s voljom spašavanja života ili tjelesne cjelovitosti životinje, protupravnost njegova ponašanja valja isključiti. To stoga jer je i sam Vrhovni sud zauzeo stajalište da se nužnom obranom može odbijati protupravni napad na svako dobro zaštićeno kaznenim pravom. Namjera slučajnog prolaznika bila je plemenite naravi te $s$ ciljem spašavanja napadnute životinje, a ne pukog nanošenja ozljeda napadačima. U navedenoj situaciji sudovi bi vrlo vjerojatno priznali nužnu pomoć slučajnom prolazniku. Kod kaznenog djela mučenja životinje zaštićeno dobro je dobrobit životinja i onaj koji životinju brani će se uvijek moći pozvati na to (kao i kod imovine, časti, ugleda i sl.) te vlastite argumente pronalaziti u odredbama Zakona o zaštiti životinja, u već spomenutoj odluci VSH (da se nužnom obranom može odbijati protupravni napad na svako dobro zaštićeno kaznenim pravom) te $u$ načelu afirmacije prava u odnosu na nepravo kod nužne obrane.

Najveće se kontroverze javljaju kod teorijskog aspekta ovog pitanja i situacije gdje bi se trebalo odstupati od standardnih dogmatskih okvira. Konkretno, postavlja se pitanje koje je pravilno tumačenje riječi „od drugog“, odnosno je li zakonodavac istim terminom i samom definicijom nužne obrane obuhvatio i životinju? Na ovo je pitanje vjerojatno teško i samom zakonodavcu dati konkretan odgovor, budući da vjerojatno nije mislio na ovakvu situaciju uopće i jer je termin „od drugog“ pomalo nespretan pojam, koji se ipak može različito tumačiti. Upravo stoga je u samom uvodu rečeno da ovdje ne leži sve na samim sudovima nego i na zakonodavcu. Nije neočekivano i nerealno za očekivati da bi ovaj teorijski aspekt mogao zadati određene nedoumice i samim sudovima.

Američka je sudska praksa kod ovog kaznenog djela, doduše u predmetima vezanim uz krajnju nuždu, također bila u velikoj nedoumici na koga se odnosi termin „od drugoga“" (engl. another). Nijedan tamošnji zakon ne donosi čisto tumačenje na koga se točno odnosi termin „od drugog“. Samim time, komparativnopravno riječ je o istoj situaciji kao i kod nas te su sudovi bili prepušteni vlastitom tumačenju istog termina. Sudovi su u tim situacijama tumačili da se termin „od drugog" ne odnosi na životinje, nego na ljudska bića, odnosno na fizičke i pravne osobe te je krajnja nužda bili neprimjenjiva u situacijama gdje je zakon prekršen u spašavanju životinja. ${ }^{42} \mathrm{U}$ predmetu State v. Le Vasseur, ${ }^{43}$ zaposlenik istraživačkog laboratorija bio je optužen za krađu nakon što je pustio dva dupina koja su u laboratoriju držana u navodno nezakonitim uvjetima. Zaposlenik je tvrdio kako je bilo neophodno ukrasti, odnosno pustiti dupine da bi se spriječilo kršenje Zakona o skrbi nad životinjama (Animal Welfare Act) koji regulira tretman nad životinjama koje se koriste za istraživanja.

42 James, J., When is rescue necessary? Applying the necessity defense to the rescue of animals, Stanford Journal of Animal Law and Policy, vol. 7., 2014.

43 State v. Le Vasseur, 613 P.2d 1328, 1333-34 (1980) 
Naime, zanimljivo je da su, prema određenim istraživanjima, u SAD-u propisima donekle zaštićeni kućni ljubimci od mučenja, ali istodobno su jako slabi propisi koji štite životinje od mučenja pri obavljanju industrijskih eksperimenata. ${ }^{44}$ Sud zaposleniku, naposljetku, nije priznao krajnju nuždu, između ostalog jer termin „zaštita drugog“, koji se koristi u havajskom zakonodavstvu kod krajnje nužde, nije smatrao primjenjivim kod dupina i drugih životinja. ${ }^{45}$

Slična je situacija i u predmetu Brooks v. State ${ }^{46}$ u saveznoj državi Floridi gdje je vozač vozio u alkoholiziranom stanju, prekoračujući dopuštenu brzinu kako bi spasio umiruću mačku vozeći je veterinaru. Iako je mačka uginula tijekom prometne gužve, sud je utvrdio kako niti vozačeva obzirnost niti patnja umiruće mačke nisu dovoljno dobar argument u odnosu na jezičnu barijeru tamošnjeg zakonodavstva gdje se ,zaštita drugog“ kod krajnje nužde također odnosi na ljudska bića. ${ }^{47}$

Ove su odluke doživjele i određene kritike u tamošnjoj pravnoj literaturi koja se bavi pravima životinja gdje se smatra kako je krajnja nužda kod oba počinitelja trebala biti uskraćena na temelju drugih činjenica, a ne isključivo zbog nedostatka osobnosti kod životinja jer su istim odlukama obeshrabrene one osobe koje bi bile potencijalni pomagači životinjama u sličnim situacijama. ${ }^{48}$ Time se naglašava važnost proširenja osobnosti i na životinje kako bi se životinje efektivnije pravno zaštitile. $^{49}$

Primjena sile radi sprječavanja mučenja životinje raspravlja se i u njemačkoj kaznenopravnoj literaturi. U poznatim komentarima njemačkog Kaznenog zakonika (StGB) zagovara se stajalište da bi takva uporaba sile mogla biti opravdana nužnom obranom jer se „ljudska samilost prema mučenoj životinji može braniti“"50. Iz navedenog proizlazi da je tu u prvom planu zaštita ljudskih osjećaja. Prema drugom shvaćanju, „drugi“ u smislu § 32 njemačkog Kaznenog zakonika može biti i životinja, tako da se počinitelj koji uporabom sile spriječi njezino mučenje može pozivati na nužnu pomoć. ${ }^{51}$ Pritom se kao važan argument navodi da „drugi““ može biti i pravna osoba ili embrij i da stoga ništa ne stoji na putu tumačenja koje i životinju smješta pod isti nazivnik (odbijanje protupravnog napada od drugoga). Takvo stajalište implicira da su život i tjelesna cjelovitost životinje zaštićena pravna dobra jer polazi od zaštite ,života i zdravlja životinja“ koja se izričito ističe u $\S$

44 Horvat, M., Povezanost mučenja životinja s međuljudskim nasiljem, Kriminologija i socijalna integracija, vol. 19., br. 1., 2011., str. 83.-98.

45 State v. Le Vasseur, op. cit. (bilj. 43.)

46 Brooks v. State, 122 So. 3d 418 (Fla, Dist. Ct. App. 2013)

47 Ibid.

48 James, J., op. cit. (bilj. 16.)

49 Ibid

50 Usp. Lenckner/Perron u: Schönke, A., Schröder, H., Strafgesetzbuch, Kommentar, 28., neu bearbeitete Aufl., Verlag C.H. Beck, München, 2010., § 32, rubni broj 8; Spendel u: Jähnke, B., Laufhütte, H. W., Odersky, W. (Hrsg.), Strafgesetzbuch, Leipziger Kommentar, Großkommentar, 11. neu bearbeitete Auflage, Zweiter Band, $\S 32$ bis 60, De Gruyter Recht, Berlin, 2003., § 32, rubni broj 189.

51 Tako Roxin, C., Strafrecht, Allgemeiner Teil, Band I, Verlag C.H. Beck, München, 2006., § 15 , rubni broj 34 . 
1. njemačkoga Zakona o zaštiti životinja (Tierschutzgesetz). No valja istaknuti da se životinja od pravne osobe i zametka ipak razlikuje po tomu što joj u potpunosti nedostaje pravna sposobnost (uključujući i njezin izvedeni oblik). Stajalište o mogućoj primjeni nužne pomoći radi sprječavanja mučenja životinje prihvatljivo je i za hrvatsko kazneno pravo. Iako životinja nema klasični pravni subjektivitet, njezinim se pravima posvećuje sve veća pozornost. To posebno dolazi do izražaja u Zakonu o zaštiti životinja (dalje u tekstu: ZZŽ) koji u članku 1. propisuje da se njime uređuju ,odgovornost, obveze i dužnosti fizičkih i pravnih osoba radi zaštite životinja, što uključuje zaštitu njihova života, zdravlja i dobrobiti“. Prema članku 4. stavku 1. ZZŽ-a, životinje je ,Zabranjeno ubijati, nanositi im bol, patnju, ozljede te ih namjerno izlagati strahu“. Iz navedenih zakonskih odredbi nedvojbeno proizlazi da su život, zdravlje i dobrobit životinja zaštićena pravna dobra. U slučaju njihove povrede ZZŽ u dijelu o kaznenim odredbama propisuje i odgovarajuće prekršajne novčane kazne. Tako će se novčanom kaznom od 50.000,00 do 100.000,00 kuna kazniti za prekršaj pravna osoba ako ,ubija životinje, nanosi im bol, patnju i ozljede ili ih namjerno izlaže strahu (članak 66. stavak 1. točka 1.). Za takve radnje prekršajno će se novčanom kaznom u iznosu od 10.000,00 do 15.000,00 kuna kazniti i odgovorna osoba u pravnoj osobi te (svaka) druga fizička osoba (članak 66. stavak 2. i 3.). Za iste kriminalne sadržaje predviđena je i kaznena odgovornost u članku 205. KZ-a, kojim se također kao pravna dobra zaštićuju život i zdravlje (uključujući i tjelesnu cjelovitost) životinje. U takvom kontekstu, a uzimajući u obzir da zakonska definicija nužne obrane ne ograničava krug pravnih dobara koja se njome mogu štititi, životinja može biti „drugi“ u smislu članka 21. stavka 2. KZ-a i njezino je ubijanje ili mučenje dopušteno sprječavati putem nužne pomoći. Shvaćanje prema kojem je nužnom obranom dopušteno braniti ljudsku samilost prema mučenoj životinji manje je uvjerljivo jer su ljudski osjećaji samo jedan od razloga koji su pokrenuli zakonodavca na pobliže uređivanje zaštite (prava) životinja. Stoga životu i zdravlju životinja kao zaštićenim pravnim dobrima valja dati prednost u odnosu na ljudski osjećaj samilosti prema njima.

\subsection{Zaštita mučene životinje primjenom krajnje nužde koja isključuje protupravnost}

Potrebno je jasno istaknuti da je rad tematski ponajprije namijenjen rješavanju problema primjene nužne obrane u slučaju mučenja životinje te da stajalište o primjenjivosti nužne pomoći ne isključuje i mogućnost primjene krajnje nužde koja isključuje protupravnost, što bi zasigurno mogla biti tema za posebno znanstveno istraživanje. Kako se radi o kaznenom djelu koje se nije previše pojavljivalo u našoj sudskoj praksi, sudovi bi se lako mogli naći u situaciji da ne znaju hoće li primijeniti nužnu obranu ili krajnju nuždu kod ovog kaznenog djela. Nužna obrana podvrsta je krajnje nužde i uži pojam od iste. O eventualnoj primjeni krajnje nužde moguće je govoriti samo u situaciji kada napadnuta životinja nije u vlasništvu nijedne osobe jer nije sporno da osoba koja brani svoju životinju od druge osobe postupa u nužnoj obrani gdje štiti svoju imovinu. 
U našem hipotetskom slučaju sa zlostavljačima mačke autor je dao prednost primjeni nužne obrane jer se sama krajnja nužda u pravilu primjenjuje u situacijama kad osoba koja postupa u krajnjoj nuždi zadire u pravna dobra trećih nesudjelujućih osoba dok su kod nužne obrane obrambene radnje upravljene prema napadaču. Odnosno, kod krajnje nužde sama radnja mora biti upravljena prema nekoj trećoj osobi, a ne napadaču. Ako slučajni prolaznik pokušava zaustaviti zlostavljača mačke tada je radnja slučajnog prolaznika upravljena prema samom napadaču, a ne nekoj trećoj osobi. Npr. ako blagajnica u banci razbojniku koji je u nju uperio pištolj preda novac banke, kazneno djelo pronevjere, čije su pretpostavke u tom trenutku ispunjene, isključeno je zbog krajnje nužde, a ne nužne obrane jer blagajnica nije povrijedila dobro napadača, nego treće osobe (banke). ${ }^{52}$ Radnja napadnutog mora biti upravljena prema nekom dobru napadača te ako napadnuti u nužnoj obrani povrijedi dobro treće osobe, njegova se radnja ima procjenjivati prema odredbama o krajnjoj nuždi. ${ }^{53}$

No, isti se slučaj može razmatrati i u okviru krajnje nužde. Naime, valja istaknuti da se u njemačkoj kaznenopravnoj literaturi razlikuju situacije agresivne i defenzivne krajnje nužde (Agresiv- und Defensivnotstand). Kod obrambene radnje (radnje odbijanja opasnosti) u defenzivnoj krajnjoj nuždi, koja zahvaća samo u sferu dobara onoga od koga potječe opasnost, dopuštena su kvalitativno i kvantitativno značajnija oštećivanja (u slučaju nužde čak i tjelesno ozljeđivanje osobe koja je uzrokovala opasnost) nego kod agresivne krajnje nužde koja u tešku situaciju uvlači treću nesudjelujuću osobu, tj. povredu njezinih pravnih dobara. ${ }^{54}$ Situacijama defenzivne krajnje nužde u kojima napad (opasnost) potječe od čovjeka tek se u novije vrijeme pridaje veća pozornost jer su se one uglavnom rješavale prema načelima nužne obrane, dok je primjena krajnje nužde koja isključuje protupravnost bila rezervirana za slučajeve agresivne krajnje nužde za koje je karakteristično da počinitelj u krajnjoj nuždi zahvaća u pravno dobro treće nesudjelujuće osobe..$^{55}$ Primjena krajnje nužde može se razmatrati i u okviru nekih drugih hipotetskih primjera, npr. spašavanje psa iz automobila razbijanjem stakla na vratima kako pas kojega je vlasnik ostavio u automobilu izloženom suncu na nekoliko sati ne bi uginuo zbog neizdržive temperature; krađa susjedova psa tijekom noći kako bi se pas spasio od svakodnevnog zlostavljanja njegova vlasnika itd.

Nadalje, treba imati na umu da primjena krajnje nužde kod ovog kaznenog djela sa sobom nosi i određena skliska pitanja gdje bismo trebali razmotriti koje je počinjeno zlo uistinu teže, odnosno je li uistinu ljudski život vrjedniji od same životinje? Pozitivistički pristup navodi nas da jest, no primijenimo li načela prirodnog prava o kojima smo govorili na početku, nećemo moći reći da je ljudski život vrjedniji od onog životinjskog. Primjenom krajnje nužde mogli bismo

52 Novoselec, P., Bojanić, I., op. cit. (bilj. 15.)

53 Ibid.

54 Usp. Wessels, Johannes; Beulke, Werner; Satzger, Helmut: Strafrecht, Allgemeiner Teil. Die Straftat und ihr Aufbau, 46., neu bearbeitete Auflage, C.F. Müller, Heidelberg, 2016., str. 143.

55 Usp. Roxin, op. cit. (bilj. 51.), § 16., rubna bilješka 72. 
razmatrati o prilično relativnim pitanjima koji svoj odgovor ne bi mogli naći u normama pozitivnog prava.

\section{ZAKLJUČAK}

Kazneno djelo mučenja ili ubijanja životinje spada u kaznena djela protiv okoliša kod kojih se otvaraju mnoga sporna pitanja, među kojima i pitanje primjene nekih klasičnih instituta općeg dijela kaznenog prava, kao što je, primjerice, nužna obrana. Stoga se ovaj rad i usredotočuje na problem nužne obrane/nužne pomoći radi sprječavanja mučenja ili ubijanja životinje. U središtu pozornosti je zaštita života i zdravlja životinje kao dijela okoliša, a ne kao dijela nečije imovine (vlasništva). Život i zdravlje životinja su pravna dobra koja su posebno zaštićena odredbama Zakona o zaštiti životinja i Kaznenog zakona. Zakonska definicija nužne obrane ne ograničava krug dobara koja se mogu štititi nužnom obranom. Stoga se istodobni ili izravno predstojeći protupravni napad na životinju kojim se ugrožava njezin život ili zdravlje (tjelesna cjelovitost) može odbijati nužnom obrambenom radnjom. Budući da se tu ponajprije radi o zaštiti života i zdravlja životinje, a ne o zaštiti ljudskih osjećaja (samilosti) prema mučenoj životinji, ispravno je stajalište prema kojemu životinja može biti „drugi“ u smislu članka 21. stavka 2. KZ-a i da je, sukladno tome, dopušteno postupanje počinitelja u nužnoj pomoći. Time se istodobno oživotvoruje i načelo potvrđivanja (afirmacije) prava u odnosu na nepravo. Prihvaćanjem mogućnosti nužne obrane kod kaznenog djela ubijanja ili mučenja životinje sudska praksa može pridonijeti prevenciji počinjenja tog kaznenog djela jer bi se time ohrabrili potencijalni pomagači, ali i obeshrabrili potencijalni napadači koji bi mogli postati svjesni činjenice da se njihovo protupravno ponašanje može i fizički zaustaviti u granicama nužne obrane/nužne pomoći.

\section{LITERATURA}

a) Knjige i članci

Knjige

1. Armstrong, Susan J., Botzler, Richard, G., The Animal Ethics Reader, Routledge, 2003.

2. Bell, Stuart, McGillivray, Donald, Pedersen, Ole, Environmental Law, Oxford University Press, Eighth edition, 2013.

3. Jähnke, Bernhard, Laufhütte, Heinrich Wilhelm, Odersky, Walter (Hrsg.), Strafgesetzbuch, Leipziger Kommentar, Großkommentar, 11. neu bearbeitete Aufl., Zweiter Band, $\S 32$ bis 60, De Gruyter Recht, Berlin, 2003.

4. Novoselec, Petar (ur.), Posebni dio kaznenog prava, Pravni fakultet Sveučilišta u Zagrebu, Zagreb, 2011.

5. Novoselec, Petar, Bojanić, Igor, Opći dio kaznenog prava, Pravni fakultet Sveučilišta u Zagrebu, Zagreb, 2013.

6. Pavlović, Šime, Kazneni zakon. Zakonski tekst, komentari, sudska praksa, pravna teorija, Libertin, Rijeka, 2015.

7. Roxin, Claus, Strafrecht, Allgemeiner Teil, Band I, Verlag C.H. Beck, München, 2006.

8. Schönke, Adolf, Schröder, Horst, Strafgesetzbuch, Kommentar, 28., neu bearbeitete Aufl., Verlag C.H. Beck, München, 2010. 
9. Turković, Ksenija i dr., Komentar Kaznenog zakona, Narodne novine, Zagreb, 2013.

10. Visković, Nikola, Kulturna zoologija, Što je životinja čovjeku i što je čovjek životinji, Naklada Jesenski i Turk, Zagreb, 2009.

Članci

1. Adams, Wendy A., Human subjects and animal objects: Animals as "other" in the law, Journal of Animal Law and Ethics, vol.3., str. 29.-51., 2009.

2. Ascione, Frank R., Children who are cruel to animals: A review of research and implications for developmental psychopathology. Anthrozoös, 6., 1993., str. 226.-247.

3. Ascione, Frank R., Lockwood, Randall (2001). Cruelty to animals: Changing psychological, social, and legislative perspectives. In D.J. Salem \& A.N. Rowan (eds.), The state of the animals, 2001., str. 39.-53., Washington, DC: Humane Society Press

4. Bačić, Arsen, Ustavni temelji i problemi zaštite okoliša u hrvatskom i europskom pravu, Zbornik radova Pravnog fakulteta u Splitu, god. 45., 4/2008., str. 727.-743.

5. Epstein, Richard A., Animals as Objects, or Subjects, of Rights, John M. Olin Law \& Economics working paper no. 171 (2D series), The Law School, The University of Chicago, December 2, 2002.

6. Horvat, Martina, Povezanost mučenja životinja s međuljudskim nasiljem, Kriminologija i socijalna integracija., vol. 19., br. 1., 2011., str. 83.-98.

7. Jakovljević, Dragan, Prava za životinje, Filozofska istraživanja, 129, god. 33., sv. 1., 2013., str. 167.-182.

8. James, J., When is rescue necessary? Applying the necessity defense to the rescue of animals, Stanford Journal of Animal Law and Policy, vol. 7, 2014.

9. Kaluđerović, Željko, Bioetički pristup životinjama, Socijalna ekologija, Zagreb, vol. 18., br. 3-4, 2009., str. 311.-322.

10. Kovačević, B., Manifest pokreta za prava životinja: o speciesizmu ili diskriminaciji na osnovi vrste, Revija za sociologiju, vol. 40., br. 3., 2010., str. 337.-343.

11. Novoselec, Petar, Sudska praksa, Hrvatski ljetopis za kazneno pravo i praksu, vol. 11., br. 1/2004., str. 279.-284.

12. Proso, Maja, Građanskopravna odgovornost u području zaštite okoliša, Zbornik radova Pravnog fakulteta u Splitu, god. 52., 3/2015., str. 705.- 719.

b) Vrela s interneta

1. Službene stranice Ius-info, viđeno: 7.6.2016.

URL: http://www.iusinfo.hr/DailyContent/News.aspx?id=14566

2. Službene stranice Ius-info, viđeno: 7.6.2016.

URL: http://www.iusinfo.hr/DailyContent/News.aspx?id=15803

c) Pravni akti Propisi

1. Kazneni zakon, NN, br. 125/11., 144/12., 56/15., 61/15.

2. Konvencija o zaštiti ljudskih prava i temeljnih sloboda, NN, MU, 18/97., 6/99., 14/02., 13/03., 9/05., 1/06., 2/10.

3. Zakon o zaštiti okoliša, NN, br. 80/13., 153/13., 78/15.

4. Zakon o zaštiti prirode, NN, br. 80/13.

5. Zakon o zaštiti životinja, NN, br. 135/06., 37/13., 125/13.

Sudska praksa

1. Brooks v. State, 122 So. 3d 418 (Fla, Dist. Ct. App. 2013)

2. Hurd v. State, 190 Md. App. 479 (Md. Ct. App. 2010)

3. State v. Le Vasseur, 613 P.2d 1328, 1333-34 (1980)

4. VSH (I Kž- 799/76, Pregled 10, 52)

5. Županijski sud u Osijeku, Kž-329/02 od 28. 6. 2002. (Općinski sud u Belom Manastiru, K-61/02) 


\section{Tomislav Nedić*}

\section{Summary}

\section{APPLYING THE LEGAL CONCEPT OF SELF-DEFENSE IN THE CRIMINAL OFFENSE OF CRUELTY TO ANIMALS}

In this paper, the author considers the issue of applying the legal concept of self-defense in the criminal offense of cruelty to animals. Starting from the legal definition of self-defense, the author raises the issue of its interpretation in the area referring to the defense of others (repelling an attack attempted by another). In particular, the author strives to address the central, but also the most controversial issue of whether the coinciding illicit attack can be repelled by an animal or whether life and physical integrity of an animal are legal goods that can be protected by means of self-defense. The author briefly analyzes the issue of legal subjectivity and objectivity of animals as well. Acknowledging the Croatian and the US jurisprudence (which jurisprudence, unlike the Croatian case law, does not consider cruelty to animals as a novelty), the author hypothetically evokes the issues that might occur before the Croatian judicial system, and how they could and should be resolved by Croatian courts. In terms of comparative law, the paper also examines the attitudes towards the use of self-defense in this type of criminal offense in German legal references. The ultimate goal of the paper is to develop a mechanism that will not discourage animal helpers, within the limits of self-defense, that is the defense of others, to prevent cruelty to an animal being, which animal being, as a part of the environment protected under the Croatian Criminal Code, is a protected legal good, and to enable an animal being to have the right to life and physical integrity (guaranteed in accordance with the principles of natural law).

Keywords: self-defense, defense of others, defense of necessity, animal, Criminal Code.

* Tomislav Nedić, mag. iur., Doctoral Student, Faculty of Law Osijek, J. J. Strossmayer University of Osijek; nedict@gmail.com 


\section{Zusammenfassung}

\section{ANWENDBARKEIT DER NOTWEHR BEI DER ALS TIERQUÄLEREI ODER TIERTÖTUNG KLASSIFIZIERTEN STRAFTAT}

In der Arbeit wird das Problem der Notwehr bei der als Tierquälerei oder Tiertötung klassifizierten Straftat behandelt. Ausgehend von der Gesetzesdefinition der Notwehr wird die Frage gestellt, wie der Teil der Definition, der sich auf die Nothilfe (Abwendung vom Angriff „des Dritten“) bezieht, ausgelegt werden soll. Konkret, es wird die kontroverste und im Mittelpunkt stehende Frage bearbeitet, ob ein rechtswidriger Angriff auch von Tieren abgewendet werden kann, beziehungsweise, ob das Leben und die körperliche Unversehrtheit von Tieren die Rechtsgüter darstellen, welche durch Notwehr zu schützen sind. Kurz wird auch die Problematik der Subjektivität und Objektivität von Tieren erläutert. Unter Berücksichtigung der kroatischen und amerikanischen Rechtsprechung (in welcher im Unterschied zur kroatischen die auf Tierquälerei und Tiertötung bezogene Rechtsprechung keine Neuigkeit ist) versucht der Autor hypothetisch darauf hinzuweisen, welche Arten von Rechtsstreitigkeiten auch vor unseren Gerichten erscheinen könnten und wie sie in solchen Fällen richten sollten. Ebenfalls werden rechtsvergleichend die Rechtsstandpunkte aus der deutschen Rechtsliteratur bezüglich der Anwendbarkeit der Notwehr bei dieser Straftat analysiert. Das Endziel ist es, ein Mechanismus zu schaffen, welcher die Tierhelfer nicht entmutigen will, dass sie im Rahmen der Notwehr, beziehungsweise der Nothilfe, die Quälerei oder Tötung von Tieren verhindern und dem Tier, welches als Teil der Umgebung ein gemäß dem Strafgesetzbuch geschütztes Rechtsgut darstellt, die Gewährleistung des Rechtes auf Leben und körperliche Unversehrtheit ermöglichen (durch Grundsätze des natürlichen Rechtes gewährleistet).

Schlüsselwörter: Notwehr, Notstand, Tier, Strafgesetzbuch, Gericht. 


\section{Riassunto}

\section{L'APPLICABILITÀ DELLA LEGITTIMA DIFESA NEL CASO DI REATO DI TORTURA O UCCISIONE DI ANIMALE}

L'autore si occupa nel lavoro della questione dell'applicabilità dell'istituto della legittima difesa nel caso di reato di tortura od uccisione di animale. Partendo dalla definizione giuridica della legittima difesa, si pone la questione della sua interpretazione nella parte in cui di riferisce allo stato di necessità (rigetto dell'aggressione „dell'altro“). In concreto si cerca di analizzare la questione centrale, ed al contempo la più controversa, e cioè se sia possibile rigettare il contemporaneo attacco illecito anche nel caso di animali. In altri termini, ci si interroga se la vita e l'integrità fisica dell'animale siano beni giuridici che possano venire protetti, invocando la legittima difesa. Si analizza brevemente anche la questione della soggettività ed oggettività giuridica degli animali. Tenendo in considerazione la giurisprudenza croata ed americana (dove, a differenza della giurisprudenza croata, la tortura o l'uccisione di animali non costituisce una novità), l'autore tenta di ricostruire ipoteticamente che genere di casi potrebbero presentarsi anche dinanzi alle nostre corti, come pure di capire come tali nostre corti affronterebbero tali casi. Ancora, da un punto di vista comparato, si confrontano gli orientamenti presenti nella dottrina tedesca con riguardo alla legittima difesa nel caso di un reato di questo tipo. Il fine ultimo è quello di creare un meccanismo che non scoraggerà gli amici degli animali, affinché nei confini della legittima difesa, ovvero dello stato di necessità, sventino la loro tortura od uccisione e consentano all'animale, il quale come parte dell'ecosistema rappresenta in forza della legge penale un bene giuridico protetto, la realizzazione (nel rispetto del diritto naturale garantito) del diritto alla vita ed all'integrità fisica.

Parole chiave: legittima difesa, stato di necessità, animale, legge penale, corte. 